\title{
Santos, Rogério (2005) As Vozes da Rádio, 1924-1939, Lisboa: Editorial Caminho
}

Helena Sousa*

A capa de um livro é a sua porta de entrada. A foto do jornal O Século de 1930 que ilumina a capa remete-nos para uma temporalidade outra. Convida-nos a uma viagem. E o mundo que a capa promete cumpre-se no interior, no texto e nas imagens. Este livro é uma surpreendente e absolutamente necessária incursão pelo passado dos media no nosso país.

Procurando perceber os primórdios da rádio em Portugal (e todo o entusiasmo que esta extraordinária invenção gerou), Rogério Santos começa a sua obra com o experimentalismo dos chamados senfilistas e chega até ao início da II Guerra Mundial.

Temos aqui um texto bem definido em termos de tempo e de espaço, mas este não fica limitado às fronteiras estabelecidas. Ocupa-se da realidade portuguesa, mas não ignora o contexto internacional da época, não esquece a Guerra Civil espanhola, o Franquismo e o Nazismo. Ocupa-se do período entre 1924 e 1939, mas esta periodização não é reducionista. Há perspectivação histórica. A análise das transformações episódicas, conjunturais e estruturais está lá e confere ao texto profundidade temporal.

O livro cobre, portanto, o fim da Primeira República (1910-1926) e o princípio do regime salazarista. Para uma melhor orientação do leitor, o autor dividiu a obra em três partes principais.

Na primeira parte, analisa todo o fascínio tecnológico da época, tanto no estrangeiro como em Portugal. A telegrafia sem fios e, posteriormente, a telefonia sem fios e a radiodifusão, constituíram desenvolvimentos tecnológicos verdadeiramente espantosos para a época. Nesta fase altamente inventiva, é de destacar o papel que os amadores desempenharam neste processo. Essa participação está, aliás, bem documentada na obra.

A segunda parte é dedicada à Sociedade e à Política. A rádio não foi, naturalmente, uma mera invenção tecnológica com todos os desenvolvimentos subsequentes. A rádio emergiu num determinado contexto político e social e os seus usos e apropriações estão inevitavelmente ligados a esse contexto. Nesta segunda parte, Rogério Santos começa por nos apresentar as denominadas 'rádios minhocas', que eram pequenas estruturas que viviam da carolice dos seus proprietários.

Mas, apesar de todo entusiasmo e de toda a carolice inicial, este período em análise não fica marcado apenas (ou essencialmente) pelo fascínio tecnológico face ao surpreendente novo meio. O potencial da rádio animou também o poder político e a intervenção do Estado não se fez esperar. O regime de Salazar criou, então, em meados dos anos 30, uma pesada (e supostamente profissional) estrutura de comunicação radiofó-

* Professora de Políticas da Comunicação e de Jornalismo na Universidade do Minho. Membro do Centro de Estudos de Comunicação e Sociedade da mesma universidade (helena@ics.uminho.pt). 
nica: a Emissora Nacional. A Emissora Nacional passou a fazer parte dos objectivos de comunicação política do regime. Reconhecendo a importância do novo meio, a Igreja Católica conseguiu, então, a devida autorização para avançar com a criação da sua rádio ainda durante os anos 30 (1937).

O destaque que a obra dá à Emissora Nacional e à Rádio Renascença é indispensável para a compreensão do duopólio (Emissora Nacional/Rádio Renascença) que dominou o panorama radiofónico nacional até à emergência das rádios-pirata nos anos 80 .

Por fim, na última parte da obra, Rogério Santos centra-se nas questões culturais relacionadas com a rádio, desde a produção de informação sobre a rádio em revistas e jornais até às questões da recepção e da formação de públicos. O último capítulo desta terceira parte dá conta especificamente da programação radiofónica e da sua evolução ao longo do tempo. As questões da programação estão naturalmente relacionadas com a criação de públicos e com os media tradicionais da época (imprensa escrita), que divulgavam não só os programas como os principais actores neles envolvidos.

Para chegar até aqui, para desenvolver e organizar este texto, foi necessário reunir um conjunto de competências e condições. Primeiro, as competências intelectuais. Doutorado em Ciências da Comunicação, Rogério Santos é também um historiador. Essa marca está bem presente. Sabe olhar o tempo e o espaço, sabe atribuir valor às fontes e dá uma grande atenção ao detalhe. Depois, as condições de trabalho necessárias (e indispensáveis) para a preparação desta obra. Com a colaboração da Torre do Tombo, da Biblioteca Nacional, da Biblioteca Municipal do Porto, da Fundação das Comunicações Portuguesas, entre outras instituições, o autor conseguiu reunir um importante conjunto de fontes primárias, sem as quais não teria sido possível levar este projecto a bom porto.

Trata-se, em suma, de mais uma importante obra de Rogério Santos e de um contributo fundamental para a história dos media em Portugal, em geral, e da rádio, em particular. 